\title{
English Subtitle Video in Teaching Vocabulary to the Junior High School Students in Palu
}

\author{
Fikri $^{1, *}$ Aminah Suriaman ${ }^{2}$ Ferry Rita ${ }^{3}$
}

\author{
1,2,3 Tadulako University \\ fikriporotuo@gmail.com
}

\begin{abstract}
The aim of this research is to find out whether the use of the English subtitle video of the eighth-grade student of SMPN Madani Palu can improve the students' vocabulary or not. The researchers applied classroom action research to solve students' problems in the vocabulary of noun, verb, adjective in the form of spelling and meaning. The subject of this research was the eighth grade BIS 1 students of SMPN Madani Palu. The participants were 21 students. The research consists of one cycle. The criterion of success was that $\geq 70 \%$ of the students must pass vocabulary score of $\geq 70$. The results of cycle 1 revealed that more than $70 \%$ of the students passed score $\geq 70$ and therefore the cycle was stopped. The result showed improvement in the students' scores from the tests. On the first test, the number of students who passed the minimum criteria of completeness (KKM) was 6 students (29\%). The number of students who passed the KKM on the second test was $16(76 \%)$. The questionnaires and the observation supports the data; it shows that the teaching-learning process ran well. The students were active and enthusiastic during the teaching-learning process with English subtitle video strategy. The strategy can help the students to solve the vocabulary problem.
\end{abstract}

Keywords: English subtitle video, junior high school, teaching, vocabulary

\section{INTRODUCTION}

Vocabulary is an important tool for the students to use language effectively. Sari and Wardani (2019) explain, "One of the elements of a language is vocabulary". It is not only used by the students, even teachers and everyone uses vocabulary as communication tools in a language to express their idea or opinion in written or oral forms. Soro (2019) States, "One of the definitions of vocabulary is knowledge of words meaning that used by people in real communication." Vocabulary is a basic component of English that is related to the four skills. Vocabulary gives the effect of all skills, without have vocabulary the students cannot master a foreign language (Ulfa et al., 2017). Spreanger (2013) also states, "One of the key indicators of students' success in school, on standardized tests, and indeed, in life, is their vocabulary". This happens because in mastering listening, speaking, reading, and writing as the four skills, students need to learn the language component which is vocabulary. Vocabulary is very important for us to know while learning English. McCarthy (1990) states that "Vocabulary is the experience of most language teachers that the single, biggest component of any language course". Vocabulary is one of the most components that need to know while learns language. It is a foundation of all language skills, where it should be improved to make language skills better.

Improving vocabulary is a good way when studies English and it makes it easier while learning a language. Alqahtani (2015) states, "Vocabulary knowledge is often viewed as a critical tool for second language learners because a limited vocabulary in a second language impedes successful communication.". In line with (Ismatullayeva, 2020) "While grammar is important, a lack of vocabulary may result in complete failure to convey a message.". Students can understand how to listen, speak, read, and write because they know about the vocabulary. That is why besides pronunciation and grammar, vocabulary becomes an important aspect to be mastered first. Teaching vocabulary is not easy because sometimes the students feel bored and get difficult to understand the word. Filimonova, (2020) states, "The problem of motivation in learning actually arises in every subject." The success of a training program, in the case of learning a foreign language, depends on the classroom atmosphere and the pedagogical materials used (Kanellopoulou, 2019). Kusumawati and Hasan (2018), state, "In English classes, we learn a lot of vocabulary 
and grammar but the learners may not know how to use it in real life". Teacher needs a strategy that can increase students' motivation with the use of technology and innovation in their class. Erdanova (2019) states, "Every year there are new opportunities and various activities in English classes, such as video technology".

The demand for mastering the English language has been increasing steadily because of advancement in science and information technology (Suriaman et al., 2018). In line with (Tarchi, Zaccoletti, \& Mason 2020) "Nowadays, learners encounter many of the information sources they engage with online. Teachers increasingly assign projects that require students to study a text or a video retrieved online" List, (2018) argues, "Notwithstanding the spread of videos as learning medium, the way students process and learn from online videos (with and without subtitles) has been under investigated in comparison to more traditional mediums, like text". Rosales (2019) states, "Motion media, like videos, is one common multimedia technology which the students are exposed to. They may watch it for academics, but most of the time for entertainment". Multimedia programs have unlimited possibilities, which makes it possible to present any type of activity in the form of animation or images. At foreign language lessons, training presentations and various information objects are most often used: lexical, grammatical material, texts, dictionaries (Axmedova and Shoazizova 2020). In line with (Zee et al., 2017) "very few studies have investigated the effects of subtitles on content learning" Sanjadireja (2020) states, "subtitle in a video helps students learn from a visual aid". Hosogoshi, (2016) confirms "Utilizing "captions" and "subtitles" onscreen textual information with audiovisual materials can help 12 learners develop listening skills using authentic materials, without modifying the speed of the material or linguistic features, such as grammar and vocabulary".

The researchers applied the English subtitle video strategy to solve the students' problems. The use of technology as audiovisual media can help the students to solve their problems.

Based on previous observation, the researchers found some problems, especially the eighth-grade students. The first problem is most of the students get difficulty in understanding words meaning. In the class, they asked many times about the words that they did not know the meaning. The second problem is they did not know how to write the words with correct spelling. The problem happens because they rarely practice in writing words. The problem comes after checking their assignment and their exam. There were some mistakes in writing words spelling. The researchers think that using English subtitle video can be the appropriate strategy in teaching vocabulary. Gambier and Doorslaer (2013) in their book, confirm that "Almost of the researcher agree that subtitles are precious learning aids for intermediate and advanced learners because they develop word recognition, pronunciation, spelling, and vocabulary building". King (2002) says subtitle video strategy in language learning has several advantages. The advantages are students can learn how to pronounce many words, consciously and unconsciously. The second, subtitles allow learners to follow the plot in the video easily. Third, learners can develop word recognition skills. The fourth, subtitles can reinforce the understanding of English context-bound expressions, and help learners to acquire new vocabulary and idioms. The fifth, subtitles can enhance students' concentration in the following lines. The last, subtitles can motivate students to study English outside the classroom context, especially by watching $\mathrm{TV}$ and cinema, listening to the original dialogues. This is in line with Aidinlou (2016) research that authentic subtitled video is effective to improve students' vocabulary, especially in long term retention. When applying strategy using English subtitle video, the students read and listen to new words. The function of the English subtitle is to make sure if there are words that the student does not understand from the video. They can write the difficult word in their book and find the meaning. The subtitle video helps students if the video uses difficult words. It also reminds the students' vocabulary that they have seen before. Through watching a video with English subtitle, it increases students' motivation to learn vocabulary because the teacher can choose kinds of video related to the material that can make the students interested in the classroom. This strategy makes the students more active to find the meaning of the words that they do not understand from the subtitle. They will try to open a dictionary because they are curious about the meaning. The strategy can improve vocabulary in form of meaning and spelling. The researchers focused on the three parts of speech only which is based on the students' needs. The parts of speech are noun, verb, and adjective which are in every meeting, the teacher taught the material by using the English subtitle video strategy.

From the explanation above, the researchers used English subtitle video as the strategy to improve the students' vocabulary, especially eighth-grade students of SMPN Madani Palu. The researcher used classroom action research to improve the teaching and learning quality. The professional teachers are those who always improve their competence continuously, always creative, innovative, and analyze the strengths and weaknesses of what has been done in the teaching and learning process, namely through Classroom Action Research (CAR) (Khairuddin et al., 2018). The researchers expect it would be an effective solution for the students to solve vocabulary problems. 


\section{RESEARCH METHOD}

The researchers used classroom action research design. The design had a cycle of action that consists of planning, acting, observing, and reflecting. The researchers used quantitative data in the form of classroom action research. The researchers conducted the research to the eighth grade students. It consisted of five classes that each class had 25-32 students. The total number of the students was about 146 . The researcher had taught there for more two years. Vocabulary is still one of the main problems while teaching English at the school. Furthermore, the researcher chose class VIII BIS1 as the action class which consisted of 25 students as the sample. The reason of selecting those classes was based on the preliminary research observation that had been conducted since the researchers were teaching at SMPN Madani Palu, this classes had some problems in learning English especially in vocabulary. The researchers' class had given a treatment as seen in the following spiral:

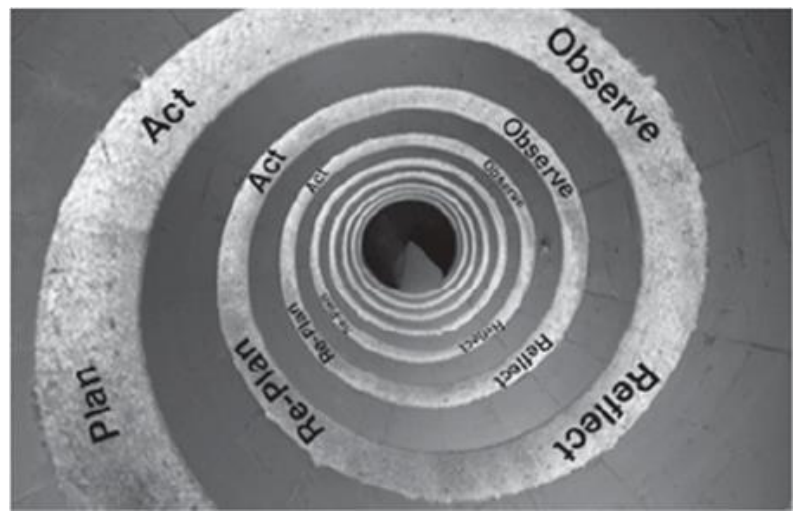

Figure 1 The Action Research Spiral

Source: Kemmis, McTaggart and Nixon (2014)

The research was conducted in one cycle where the cycle consisted of four meetings. In this research, there were data that was needed to be analyzed. The first was data from student's questionnaire. The second was the data from students' test. The function of questionnaire was to support the data from the test. The data from the test showed the activities in the class and the students' response with English Subtitle Video strategy.

\section{FINDINGS}

In this research, the researchers analyzed the data collected from 21 students of the grade VIII BIS1 students of SMPN Madani Palu in the academic year 2019/2020. The researchers conducted online research, it was because there was no activity at school since Corona virus disease. The data was collected from google classroom and google form. The researchers used google classroom to teach in the class and to give video materials. Google form was used by the researchers to collect the data from the tests and the questionnaires. The total student in the class was 25 , but the participant was only 21 students. The data consisted of tests and questionnaires. The data of cycle 1 showed the improvement of the students' achievement in vocabulary. The questionnaires also showed the students' motivation in learning English vocabulary through English subtitle video.

\subsection{Results of the Pre-test}

The pre-test was conducted to know the student's vocabularies in form of meaning and spelling. The result of the test was expected to help the teacher in knowing the students' problems in vocabulary. In the pre-test, the researchers gave students several questions. The type of tests was multiple-choice, completion, and making sentences. The tests focused on vocabulary noun, verb, and adjective. The pre-test was conducted on Thursday, April 16th, 2020. The students got the pre-test at 9.00 a.m. It spent about 30 minutes.

From the percentage of the correct answer, the most difficult item in the vocabulary test was in making a sentence. Many students could not answer and they made mistakes. Only six students achieved the minimum criteria of completeness.

After counting the pre-test score of the students, the researchers calculated the mean score of the students by applying the formula which is proposed by Arikunto (2006), as follows:

$M=\frac{\sum x}{N}=\frac{1230}{2}=59$

To get the percentage of students who achieved the KKM score, the researchers used the following formula proposed by Purwanto (2012):

Successful Percentage $=\frac{\text { Total successful students }}{\text { Total students } \text { join the test }} \times 100$

Successful Percentage $=\frac{6}{21} \times 100$

Successful Percentage $=29 \%$

Based on the result of the pre-test, the data showed that the mean score was 59 . There were only 6 students who got the minimum criteria of completeness (KKM) meanwhile the 15 students under the criteria. As can be seen that most of the students' vocabulary was still very low. So, the researchers needed to find a solution to overcome this problem. The researchers used English subtitle video in teaching English vocabulary. 


\subsection{The Results of Pre-questionnaire}

The pre-questionnaire was given to the students on Thursday, April 16th, 2020. The questionnaire has ten questions which were revealed in three categories, they were the students' responses about the teaching and learning process, the result of the students' vocabulary learning activity and the solution to the problems in vocabulary.

The first category was the students' response to the teaching and learning process of English vocabulary. The result showed $100 \%$ of students enjoyed in teaching and learning process. The next item was the students' understanding of English materials. It showed that only $43 \%$ of the students understood the teacher's explanation. Based on the data above, it can be concluded that all students like English subject, even though they did not master English vocabulary yet.

The second category was the result of students' learning activity. It showed that $71 \%$ of the students were not satisfied with their scores in English. It was bigger than those who were satisfied. Then, only $42 \%$ of the students could answer the teacher's questions about the material. It could be drawn that most of the students had not reached a good score which passed the minimum criteria of completeness (KKM).

The last category asked about the solution to the problems in English learning. For the first item, some students asked their difficulties to the teacher, it was about $38 \%$. It was indicated that many students were not actively involved in the teaching and learning process. The second item was $85 \%$ of students said that their teacher implemented a suitable technique to solve difficulties in English learning. Then, most of the students answered that the technique of the teacher could help them to find out the vocabulary easily and get the new vocabulary, it was about $100 \%$ of the students. The next item, $85 \%$ of students said that their teacher gave exercise to develop their vocabulary. Based on the students' answer above, it indicated that the teacher had already done a good effort to help her students in mastering vocabulary. In contrast, $62 \%$ of students couldn't do the task easily. It means that most of them still had problems learning English. It was known from the last result of the last question, there we only $19 \%$ of the students stated that they had many vocabularies. The result implied that the students should get extra efforts to improve their English. One of the ways is improving students' vocabulary because there were many students who still low in vocabulary.

Related to the result of the pre-questionnaire above, it can be concluded that there was a strategy needed to improve students' achievement in English. Therefore, classroom action research was done.

\subsection{Findings of Cycle 1}

\subsubsection{Planning}

In this research, the researchers wanted to improve the students' problems in the classroom. Therefore classroom action research was conducted. As the teacher in that school, the researchers had known well the students that their involvement in the teaching and learning process was still low. This means that most of them did not interact actively during the teaching and learning process which then resulted in their achievement in English. They had passive English and were having difficulties to produce sentences on their own.

For all those reasons, the researchers planned the action carefully dealing with preparing video in English subtitle, instructional materials, media, and determining the criteria of success. In this phase, the researchers made planning for the action research based upon the problems faced by students about vocabulary. In this case, the researchers determined selected materials and exercises into the lesson plan. Based on the syllabus, there are some kinds of text this semester, they are descriptive and recount text. The descriptive text was chosen as the text to be delivered for students. That was a vocabulary that consists of part of speech especially noun, verb, and adjective. In the lesson plan, there were some explanations to identify the part of speech.

Besides making a lesson plan, the researchers also prepared the post-test to find out if there are students' improvement scores from pre-test to post-test. Next, the researchers will determine the criteria of success. The criteria of success were first, $70 \%$ of the students achieved Minimum Criteria of Completeness of English (70) or above 70.

\subsubsection{Acting}

The actions of the cycle-I were done on April 16'“, $17^{\circ "}, 20 "$ ", and 21" 2020. All the activities were planned carefully before the actions were implemented. The researchers conducted this research via google classroom. The tests and the questionnaires are given through google form. Meanwhile, the researchers implemented the teaching and learning process based on the lesson plan had been made. In the first meeting, before involving students in English subtitle video strategy, the researchers told them how to study using English subtitle video. Finally, the researchers asked the students to make some sentences from the words on the English subtitle video. 


\section{1). The First Meeting}

The first meeting was conducted on Thursday, 16'th April 2020. Some activities of teaching vocabulary using English subtitle video strategy in the first meeting were as follows:

(1) Implemented the teaching-learning process based on the lesson plan.

(2) Introduced the students how to learn using English subtitle video.

(3) Asked the students to mention all nouns and adjectives in the text.

(4) Asked the students to focus on the subtitle

(5) Guided the students to write the words from the subtitle video

(6) Asked the students to translate the words

(7) Gave the English example of how to use the words.

(8) Gave the evaluation to make a sentence from several words in the video.

\section{2). The Second Meeting}

The second meeting was conducted on Friday, 17'th April 2020. Some activities of teaching vocabulary using English subtitle video strategy in the first meeting were as follows:

(1) Implemented the teaching-learning process based on the lesson plan.

(2) Introduced the students how to learn using English subtitle video.

(3) Asked the students to mention all nouns and adjectives in the text.

(4) Asked the students to focus on the subtitle

(5) Guided the students to write the words from the subtitle video

(6) Asked the students to translate the words

(7) Gave the English example of how to use the words.

(8) Gave the evaluation to make a sentence from several words in the video.

At the end of this meeting, the students produced 5 sentences based on the words from the subtitle video.

3). The Third Meeting
The third meeting was conducted on Monday, 20'th April 2020. Some activities of teaching vocabulary using English subtitle video strategy in the first meeting were as follows:

(1) Implemented the teaching-learning process based on the lesson plan.

(2) Introduced the students how to learn using English subtitle video.

(3) Asked the students to mention all nouns and adjectives in the text.

(4) Asked the students to focus on the subtitle

(5) Guided the students to write the words from the subtitle video

(6) Asked the students to translate the words

(7) Gave the English example of how to use the words.

(8) Gave the evaluation to make a sentence from several words in the video.

\section{4). The Fourth Meeting}

The fourth meeting was conducted on Tuesday, $21^{\text {'th }}$ April 2020. Some activities of teaching vocabulary using English subtitle video strategy in the first meeting were as follows:

(1) Implemented the teaching-learning process based on the lesson plan.

(2) Introduced the students how to learn using English subtitle video.

(3) Asked the students to mention all nouns and adjectives in the text.

(4) Asked the students to focus on the subtitle

(5) Guided the students to write the words from the subtitle video

(6) Asked the students to translate the words

(7) Gave the English example of how to use the words.

(8) Gave the evaluation to make a sentence from several words in the video.

\subsubsection{Observing}

In this cycle, the researchers had observed the students' participation in vocabulary teaching and learning. Many of the students were active in the class. They were asking about what they did not know. The 
students also followed all of the steps in studying with English subtitle video.

In the first meeting, the researchers found the students were interested in the lesson given through English subtitle video, but there was a problem in deciding the part of speech of the words. The students did not understand well which one is noun, verb, or adjective. This could be understood as new learning for the students. The students could not concentrate on the explanation given by me about noun, verb, and adjective. In other words, they were still confused about how to differentiate the different parts of speech. They could not understand well about part of speech. It was known from their scores on the worksheet given, they were confused in making sentences.

In the second meeting, the researchers saw a better classroom condition. They already knew how to write sentences by practicing it. In this meeting the researchers still found the same problem from the students, they had difficulties to differentiate noun, verb, and adjective. The students were asking some of the categories before they write the words that they got from the subtitle video. The students were also confused about some of the meanings of the words. It was known by how they respond to my questions while asking the translation of the words.

In the third meeting, the researcher found that the class was in a good condition. Students searched the category of the words in their dictionary. The researchers only reviewed and corrected students' words. They had not asked about the part of speech. They listened to my explanation about part of speech (noun, verb, and adjective) seriously. They did their task to find words from the subtitle video, to translate the word, and to practice making sentences. However, the students still spent a lot of time to produce a sentence.

In the fourth meeting, the researchers found the class ran well. Students enjoyed vocabulary learning. It can be seen from the post questionnaire of the students. The researchers reviewed all materials and students' works. It showed that the students had an improvement in the teaching-learning process. They could understand the parts of speech of the words in subtitle video. The students could differentiate the part of speech (noun, verb, and adjective). They also could make sentences in the simple present tense with correct structure, spelling, and meaning.

\subsubsection{The Result of Post-test (Cycle 1)}

The post-test was given on Tuesday, 21"Th April 2020 after the researchers applied the English subtitle video strategy. The post-test was done for about 30 minutes. The post-test was given to find out the students' improvement in mastering vocabulary after they learned by English subtitle video.

There were also 30 questions given to the students in this post-test. The type of tests was multiple-choice, completion, and making sentences. The tests focused on vocabulary noun, verb, and adjective. Then, each score was converted to a percentage of 100 scales to rank the students' achievement and improvement after being taught with English subtitle video.

The data show that the mean score was 78 . There were five students or $24 \%$ of the students who got the score above the minimum criteria of completeness, and the other sixteen students had passed the minimum of completeness criteria. However, there was a significant result of students who achieved the Minimum Criteria of Completeness (KKM). Comparing the result of the first test, it also indicated that there was an improvement in students' vocabulary mastery after being taught with English subtitle video. The mean score of the students increased from 59 to 78 . There was an increase in the score as many as 19 points. This becomes one of the indicators in the success of the implementation of this strategy.

To get the percentage of students who achieved the KKM score, the researchers used the following formula:

Successful Percentage $=\frac{\text { Total successful students }}{\text { Total students } \text { join the test }} \times 100$

Successful Percentage $=\frac{16}{21} \times 100$

Successful Percentage $=76 \%$

At the end of cycle 1, there were 16 students achieved more than the minimum score expected, which was 70 . The percentage of students who were successful in this test was $76 \%$. This number had improved significantly from $29 \%$ in pre-test cycle 1 . The success percentage of $76 \mathrm{had}$ also strengthened the result of the test done by the students.

The next is to compare the result of the test with the previous one. The result in the pre-test and post-test showed significant improvement. 


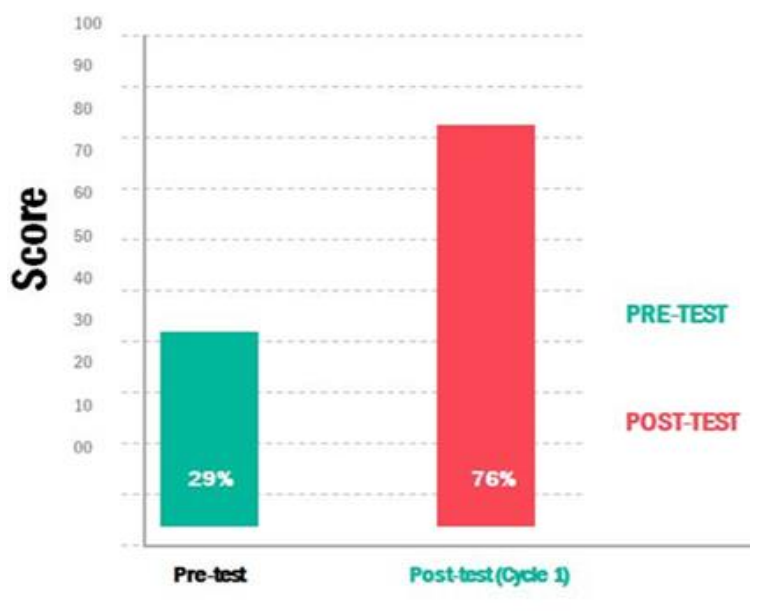

Figure 2 The Improvement of Students' Score (Cycle1)

The data showed that the mean score of the post-test (Cycle 1) was 78. When compared to the pre-test, the mean score was 59. Then, the mean score improved 19 in the cycle. It implied that the criteria of success have fulfilled. There was an increase in the mean score. The same thing appeared to the successful percentage of the students who achieved the KKM in the cycle. Therefore, it can be concluded that the use of English subtitle video improved the mean score as well as the successful percentage of mastery of the students.

\subsubsection{Reflecting}

Based on the analysis of the students' scores in the post-test, the researchers have achieved the criteria of success that is $70 \%$ of students must pass the KKM. As can be seen that $76 \%$ of students who got a score above the KKM. So, the implementation of the English subtitle video strategy has given a satisfactory result. Because of the satisfying result, the researchers decided to stop the action. The researchers concluded that the students could use English subtitle video as the media in improving the vocabulary in their mind. Based on the result in the cycle, the improvement of teaching activity can be summed up as follows:

(I) Teacher explained clearly how to study using English subtitle video. To ensure that, the teacher also explained the way to use English subtitle video in Bahasa Indonesia.

(2) Teacher limited the time for the students in finding the vocabularies from the subtitle video. He limited 20 minutes to find words in the form of noun, verb, and adjective.

(3) Teacher monitored the students' progress by looking at students' work during their discussion time in finding and mentioning the words. He asked all the students to ensure that all students found and wrote the words in the class.

(4) Teacher ensured that the students understand clearly about parts of speech by explaining to the students during the teaching-learning process. He even gave some examples in Bahasa Indonesia to help the students differentiate parts of speech.

(5) Teacher ensured that all the students were motivated to work actively in class. This was done when he asked some students in some activities.

(6) Teacher motivated all students to find at least five words of noun, verb, or adjective to help the students who were confused about several words. He ensured that everyone worked cooperatively and efficiently by asking students one by one about the part of speech they had contributed to the class.

(7) The mean score in vocabulary mastery had improved from pre-test to post-test. By the end of cycle 1, the mean score had improved more than the indicator stated to achieve that was more than 70 .

As a result of the improvement in students' scores on the test, then the classroom action research was successful. The improvement in the mean score of the test also shows the students' ability to solve vocabulary tests improved along the way. The same thing went to the teaching and learning process in which students felt satisfied with the way of teaching being implemented by the teacher. Therefore, it can be concluded that the teaching of vocabulary by using English subtitle video strategy at grade VIII BIS students of SMPN Madani Palu was effective to improve successful criteria and the mean score of the students.

\subsection{The Result of Post-questionnaire}

Besides giving a questionnaire before implementing the English subtitle video strategy in the classroom, the researchers also gave the questionnaire to the students after implemented the strategy. The post-questionnaire was conducted on Wednesday, 22'th April 2020. This questionnaire was used to find out the students' responses after learning vocabulary using English subtitle video strategy. The questionnaire had ten questions which were broken down into three categories: they are students' responses about the teaching and learning process, results of students' vocabulary learning activity, and the last students' responses about English subtitle video.

The first category was the students' response to the teaching and learning process. Based on the data, almost all students said yes, it indicated that the students were interested in the teaching and learning process using English subtitle video strategy. The next item was 
students' motivation in learning English using English subtitle video. It showed that $100 \%$ of the students want to join the English class. The last item was about a comparison between learning English using English subtitle video strategy than the usual strategy. It was about $86 \%$ of the students felt better learning English using English subtitle video than the usual strategy.

The second category was the result of the students' vocabulary learning activity. The data indicated that $86 \%$ of students were helped in enriching their vocabulary through English subtitle video. The next item showed that $86 \%$ of students could do the English task easily by using English subtitle video strategy. The last item was students' understanding about the part of speech (noun, verb, and adjective), $86 \%$ of students agreed that they had learned many words and understood the part of speech when the teacher used the English subtitle video strategy.

The third category was the students' responses to the English subtitle video strategy. The first item in this category asked about students' opinions about English subtitle video, $90 \%$ of students agreed that they felt better in learning English through English subtitle video. The second item indicated that $86 \%$ of students more understood the vocabulary easily after applying English subtitle video. The next item was $95 \%$ of students felt that English subtitle video could facilitate them in learning English vocabulary. It means that English subtitle video could help them to improve their vocabulary. Finally, the result showed that $90 \%$ of the students could memorize both their previous vocabulary and the new one.

To sum up, it indicated that most of the students agreed that English subtitle video can help them to improve their vocabulary. The result of all the items in the questionnaire supported the result found on students' mean scores and successful percentage.

\section{DISCUSSION}

As stated in the above, this research aimed to find out whether the use of the English subtitle video of the eighth-grade student of SMPN Madani Palu can improve the students' vocabulary or not. This research was formulated after conducting the preliminary observation in the teaching and learning process. The result of preliminary research indicated that the students had some problems in vocabulary. First, the students could not use words in the correct spelling. Second, the students did not understand the meaning of words such as noun, verb, and adjective.

Based on the data, it is showed that there is an improvement to the class of the research. The researchers use tests and questionnaires to find the students' improvement. The tests are pre-test and post-test. The pre-test is used to know the vocabularies of the students before the English subtitle video applied in the class. The test is given to know the students' vocabularies of noun, verb, and adjective in the forms of meaning and spelling. The kinds of the test are multiple-choice, completion, and making sentences which is the total number of the test are 25 and the total score of the test are 30.

The researchers give the pre-questionnaire first and conduct a pretest on Thursday, April 16th, 2020. Most of the students get a low score in the pre-test. Only six students achieved the minimum criteria of completeness. Some problems cause the students to get a low score in the pretest, such as; they had a lack of vocabulary especially in noun, verb, and adjective; they could not understand the meaning of the words in the test, and they could not write English words with correct spelling.

After conducting the pre-test and pre-questionnaire in the class, the researchers apply the English subtitle video strategy in four meetings. The researcher teaches about simple present tense which is in every meeting they watch a different video with English subtitle. The researchers focus on students' vocabulary of noun, verb, and adjective.

After applying the strategy, the post-test is conducted. The post-test is conducted to find out the progress of students' vocabularies. The researchers conducted the post-test on Tuesday, April 21st, 2020. There is an improvement in the result of the class. In the pre-test, there were just six students who achieved the minimum criteria of completeness. The mean score of the test was only 59 . The result shows that there were only $29 \%$ of students achieved the minimum criteria of completeness. The result is different from the post-test which sixteen students achieved the minimum criteria of completeness, the mean score was 78 , and there were $76 \%$ of students had achieved the minimum criteria of completeness. It shows that the class has an improvement in the teachinglearning process by using the English subtitle video. Then, to know the students' responses while study with the English subtitle video, the researchers gave the postquestionnaire the next day after giving the post-test. The post-questionnaire shows that most of the students are satisfied with this strategy in learning vocabulary. Furthermore, the researchers stop the cycle and conclude that using English subtitle video can improve students' vocabulary of the eighth grade BIS 1 students of SMPN Madani Palu.

There are several strengths of the English subtitle video strategy that make the students achieve the improvement of vocabularies in form of meaning and spelling. The strengths of this strategy are presented in the following paragraphs:

First, students can work together where they listen, write, and share some words that they get from the 
subtitle video. It causes them to comprehend more about the materials. While some students write the words in the class, the others also get new words. It is happening because they got different words from the subtitle video. Kurbanova, (2020) states,"our own observations show that often students who are fluent in the language are willing to help other students with a lower level." By teaching with this strategy also, the students who got difficult in understanding the context or words in the teaching-learning process get a chance to learn from their friends.

Second, the students can get words especially the vocabulary in form of meaning with this strategy. They get words from what they find in the video materials. The researchers limit the words only to noun, verb, and adjective. It is to make sure that the students focus to learn the three categories of words with a limited time which is only 80 minutes every meeting. With this strategy, they translate the words from what they get in the video materials and also from what their friends get. They share the words in the class which is can improve their vocabulary in the form of meaning.

Third, this strategy can practice the students to write words in form of spelling. They practice how to write the words from what they get in the video with the correct spelling. It is not only writing the words, they also practice writing sentences based on the words in the video materials. It can be a good strategy in practicing students spelling with the related materials while the student share words and practice how to use the words in sentences.

Fourth, this strategy makes the class more fun and comfortable. It can be seen in the result of the postquestionnaire. This happens because students can learn in different ways. The researchers also can choose the kind of video that is related to the materials that can make the students interest in the classroom. The students are very enthusiastic when they watch video materials. Sometimes the researchers ask the other students to translate and to write sentences based on the words from their friends. It makes the students fun and comfortable because the teaching process is very attractive.

The fifth, subtitles can motivate the students to study English outside the classroom context, especially by watching TV, cinema, and the internet. Internet provides a video with the subtitle. The Internet is a rich storehouse of authentic, up-to-date material (texts, audio, video, etc.) and information, as well as means and opportunities for communication and building platforms that allow the exchange of ideas, opinions, and achievements (Bobokulova, 2019). For example, Youtube, Vimeo, Metacafe, and Myspace. The students can learn new vocabulary with this strategy at home. Without time- limited, they can learn more vocabulary not only in noun, verb, and adjective category.

There are also some problems when the researchers applied the English subtitle video in his research. The first problem is the students focus only on the words of the video materials. They do not care about the content of the video. For example, when the students write sentences in the simple present tense. They still make a mistake even in the video there is a formula to use the simple present tense in a sentence. But this problem can be solved with the tasks that make the students pay attention to the content of the material. The teacher can ask the student about the content or ask the students to conclude what they get from the video.

The second problem is about part of speech. For students in junior high school, it is quite difficult for them to differentiate the category of words. In the teachinglearning process, they were always asking about the category. The most category that was very difficult for them was adjective. They were asking more about adjective from the video or the translation. This happens because when they study English, they only focus to increase their vocabulary without pay attention to the part of speech. As the result, they are confused to use some words in constructing a sentence. This is the role of the teacher in the classroom. The teacher should explain first about part of speech to make this strategy more effective.

This research results in line with the previous study conducted by Nasab and Motlagh (2017). Nasab and Motlagh (2017) confirm in their study that "subtitling is an efficient factor which has a high impact on vocabulary learning." Yildiz, (2018) also states that "The vocabulary information based on visual context or movie, helped the participants to learn and retain more effectively than the other strategies showed in the pre-and-post tests." It can be concluded that English subtitle video can improve students' vocabulary in form of meaning and spelling. The researchers had also observed the improvement of the students in the class with this strategy. The researchers found that the students have learned how to use vocabulary based on the category of part of speech in the subtitle and this strategy can motivate students to learn English.

\section{CONCLUSION}

The implementation of English subtitle video improves the students' vocabulary. The result shows that there are improvements in the students' successful percentage and the mean score from the cycle I. The successful percentage improves $47 \%$ and the mean score improves from 59 to 78 . The questionnaires also support the data in which most students study vocabulary better with the strategy. English subtitle video solves the students' problems of vocabulary in the form of meaning 
and spelling. The students get new vocabularies and they learn how to use the vocabulary based on the category of part of speech that found in the subtitle video. The findings also imply that the strategy potentially increase students' motivation to learn English.

Dealing with the conclusions above, the researcher would like to give suggestions for English teachers, students, and the next researchers. For English teachers, the researchers suggest to choose video with a slow speed. Sometimes the students cannot get the words on the video subtitle because the speed of the video. The teacher also can limit the word category not only in noun, verb, and adjective, but they can limit the word category based on what the students need related to the topic. For the students, if they want to improve their vocabulary. They can use this strategy at home. The students just need to find video that is related to the materials. They should find video with English subtitle video. The students should watch the video and if they have difficult words from the subtitle video, they can find the meaning of the word from dictionary. The last for the future researchers, if they want to solve problems in vocabulary, they can conduct similar strategy to the other level of students. First, they should decide the part of speech which most of the students feel confused, so they can decide the video that related to the topic and make the appropriate scope of the research based on students need.

\section{ACKNOWLEDGMENTS}

We would like to say thanks to the students of class VIII BIS 1 in the 2019/2020 academic year at SMPN Madani Palu who have participated in the study.

\section{REFERENCES}

[1] Aidinlou, N. A. and Moradinejad, A. (2016). Shortterm and Long-term Retention of Vocabulary through Authentic Subtitled Videos. Advances in Language and Literary Studies. 7, 5 (Oct, 2016), 1422.

DOI:http://dx.doi.org/10.7575/aiac.alls.v.7n.5p.14.

[2] Alqahtani, M. (2015). The Importance of Vocabulary in Language Learning and How to Be Taught. International Journal of Teaching and Education. III, 3 (Jan, 2015), 21-34. DOI:https://doi.org/10.20472/TE.2015.3.3.002.

[3] Arikunto, S. (2006). Prosedur Penelitian: Suatu Pendekatan Praktek (Edisi Revisi VI). Jakarta: Binapura Aksara.

[4] Axmedova, Z., and Shoazizova, A. (2020). Modern innovation methods of teaching english. ISJ Theoretical \& Applied Science. 5, 85 (May, 2020),
873-875.

DOI:

https://dx.doi.org/10.15863/TAS.2020.05.85.163.

[5] Bobokulova, G. S. (2019). Innovative methods of teaching English. ISJ Theoretical \& Applied Science. 12, 80 (Dec, 2019), 583-588. DOI: https://dx.doi.org/10.15863/TAS.2019.12.80.112.

[6] Erdanova, S. A. (2019). Modern methods of teaching English. ISJ Theoretical \& Applied Science. 10, 78 (Oct, 2019), 611-613. DOI: https://dx.doi.org/10.15863/TAS.2019.10.78.111.

[7] Filimonova, L. Y. (2020). Pedagogical and psychological characteristics of motivation in studying a foreign language. ISJ Theoretical \& Applied Science. 1, 81 (Jan, 2020), 615-618. DOI: https://dx.doi.org/10.15863/TAS.2020.01.81.103.

[8] Gambier and Doorslaer (2013) Handbook of Translation Studies. Amsterdam: John Benjamin Publishing.

[9] Hosogoshi, K. (2016). Effects of captions and subtitles on the listening process: Insights from EFL learners' listening strategies. The JALT CALL Journal. 12, 3 (Dec, 2016), 153-178. DOI: https://doi.org/10.29140/jaltcall.v12n3.206.

[10] Ismatullayeva, I. I. (2020). Some ways of teaching vocabulary through interaction at the English lesson. ISJ Theoretical \& Applied Science. 1, 81 (Jan, 2020), 563-566. DOI: https://dx.doi.org/10.15863/TAS.2020.01.81.93.

[11] Kanellopoulou, C. (2019). Film Subtitles as a Successful Vocabulary Learning Tool. Open Journal of Modern Linguistics. 9, 2 (Apr, 2019), $145-152$

DOI: https://doi.org/10.4236/ojml.2019.92014.

[12] Kemmis, S,. McTaggart, R. \& Nixon, R. (2014). The Action Research Planner: Doing Critical Participatory Action Research. Singapore: Springer.

[13] Khairuddin, I., Alwi, N. A., and Helsa, Y. (2018). Classroom action research for improving teacher's profesionalism. In Proceedings of 5th ICMSE, Journal of Physics: Conference Series, 1321, 1-3. DOI:https://doi.org/10.1027/1864-1105/a000208.

[14] King, J. (2002). Using DVD Feature Films in the EFL Classroom. In Computer Assisted Language Learning. 15, 5 (Dec, 2020), 509-523. DOI:https://doi.org/10.1076/call.15.5.509.13468.

[15] Kurbanova, M. M., and Ataeva, G. B. (2020). Problems facing EFL teachers in mixed ability classes and strategies used to overcome them. ISJ Theoretical \& Applied Science. 1, 81 (Jan, 2020), 
721-725.

DOI: https://dx.doi.org/10.15863/TAS.2020.01.81.127.

[16] Kusumawati, E. and Hasan. (2018). Implicit Instruction, Subtitles, Vocabulary and Listening Comprehension. Alphabet. 1, 2 (Nov, 2018), 129135.

DOI: https://doi.org/10.21776/ub.alphabet.2018.01.02.06

[17] List, A. (2018). Strategies for comprehending and integrating texts and videos. Elsevier Ltd. 57, (Oct, 2018),

34-46. DOI:https://doi.org/10.1016/j.learninstruc.2018.01. 008.

[18] Mccarthy M. (1990). Vocabulary. New York: Oxford University Press.

[19] Nasab, M. S. B. and Motlagh S. F. P. (2017). Vocabulary Learning Promotion through English Subtitled Cartoons. Communication and Linguistics Studies. Special Issue: Applied Linguistics in Line With TEFL. 3, 1 (Jan, 2017), 1-7. DOI:10.11648/j.cls.s.2017030101.11.

[20] Purwanto, N. (2012). Prinsip-Prinsip dan Teknik Evaluasi Pengajaran. Bandung: Rosdakarya.

[21] Rosales, A. (2019). Vocabulary Acquisition (Incidental) through Watching Subtitled Video Material. ELT Forum: Journal of English Language Teaching. 8, 2 (Nov, 2019), 190-197. DOI:https://doi.org/10.15294/elt.v8i2.33356.mo.

[22] Sanjadireja, R. 2020. Subtitle in Teaching Pronunciation with Video. IJET (Indonesian Journal of English Teaching). 9, 1 ( Jul, 2020), 67-85. DOI:https://doi.org/10.15642/ijet2.2020.9.1.67-85.

[23] Sari, wa, N. M., and Wardani, Niken, A. K. (2019). Difficulties Encountered By English Teachers In Teaching Vocabularies. Research and Innovation in Language Learning. 2, 3 (Oct, 2019), 183-195. DOI: http://dx.doi.org/10.33603/rill.v2i3.1301
[24] Soro, S. H. (2019). Analysis of English Vocabulary in the Mind of Student. International Journal of Nusantara Islam. 7, 2 (August, 2019), 220-229. DOI:https://doi.org/10.15575/ijni.v7i2.5802.

[25] Spreanger, M (2013) Teaching the Critical Vocabulary of the Common Core. Alexandria: ASCD.

[26] Suriaman, A., Rahman, A. and Nony, N. (2018). Developing Web-based English Instructional Material Oriented to Promote Independent Learning at Indonesian University Context. Journal of Language Teaching and Research. 9, 2 (Mar, 2018), 336-345.

DOI: http://dx.doi.org/10.17507/jttr.0902.15.

[27] Tarchi, C., Zaccoletti, S., and Mason, L. (2020). Learning from text, video, or subtitles: A comparative analysis. Elsevier Ltd. 160, (Sep, 2020), 1-22. DOI: https://doi.org/10.1016/j.compedu.2020.104034.

[28] Ulfa, F., Salim, A. and Permana, D. (2017). Teaching Vocabulary Using Cartoon Movie at Sdn Bunklotok Batujai Lombok Tengah. Journal of Languages and Language Teaching. 5, 1 (May, 2017), 23-27. DOI: https://doi.org/10.33394/jollt.v5i1.330.

[29] Yildiz, T. C. (2018). The Effect of Movies on Inference the Meanings of Vocabulary: Turkish L2 Learners of English. International Journal of Humanities and Social Science. 8, 12 (Dec, 2018), 88-94.

DOI: http://dx.doi.org/10.30845/ijhss.v8n12p1.

[30] Zee, T. Van Der, Admiraal, W., Paas, F., Saab, N., and Giesbers, B. (2017). Effects of subtitles, complexity, and language proficiency on learning from online education videos. Journal of Media Psychology. 29, 1 (Mar, 2017), 18-30. DOI: https://doi.org/10.1027/1864-1105/a000208. 